\title{
FREQUENCY OF HEARING IMPAIRMENT IN METAL INDUSTRY AND REPERCUSSION ON PROFESSIONAL ENABLING OF DEAF
}

\section{Husnija Hasanbegović ${ }^{1}$ \\ Esad H. Mahmutović}

Faculty for education and rehabilitation, University of Tuzla

Center for education and rehabilitation of hearing impairments Tuzla
UDC 616.28-008.14:669-057.22(049.5) $331.472(049.5)$

Received: 12.01.2011

Accepted: 04.05.2011

\begin{abstract}
The survey has been done on sample of 1252 people. The target was to estimate damage of noise on professional rehabilitation of deaf population, which is mostly directed to professions in heavy industry, for professions in metal industry. Sample has been divided to 3 sub samples: 137 hearing people in metal industry; 106 hearing impaired adults with different professions and control group of 1000 hearing people. The results of survey point that work conditions contribute to hearing damage at employers in metal industry by comparison with hearing impairment of usual population. By comparative analysis of registered hearing impairments concerning age, statistically important difference in frequency of hearing impairment of two sub samples $(t=3.27$, sing $=.05)$. The relation between hearing impairment and years of working has been identified at employers in heavy industry, (r=.37).
\end{abstract}

Key words: professional rehabilitation, noise, metal industry

\section{INTRODUCTION}

A hearing impairment may present a great obstacle for the realization of the particular work tasks or may be a serious risk for the workers with and without this kind of damage through the work process.

The sense of hearing should be continually controlled in order to prevent the appearance or to re- duse possible progress of the professional hearing impairment through the work conditions where the noises and the vibration present the serious risk for the hearing damaged.

Workplaces under these conditions are considered as the workplaces with the special work conditions in the relation to the hearing requirements and the damaged exposure of the hearing.

1 Correspodence to:

Husnija Hasanbegović, PhD, Faculty for education and rehabilitation, University of Tuzla

Univerzitetska 1, 75000 Tuzla, Bosnia and Herzegovina,

Phone: +38761739089

E-mail: husnijamaj@hotmail.com 
In order to establish which one of the work process is really danger and harmful it is necessary not used to discover the existence of the danger or damage but also to find out what kind of damage is about, to find out the manner of action and the relation dose-efficiency (Bogati-Šare).

According to the definition of the international work organization, the professional diseases are directly connected with the work damage and condition, and these diseases are mostly caused by one causal factor at work places (ILO, 1998). Mentioning the noises, which is usually the main cause of hearing impairment in the industry, it is necessary to measure the level of noises through the work process, including the octave analysis, because the human ear reacts differently on the harmful effect of the different noises frequency. The level of noises for keeping sense of hearing is to $90 \mathrm{~dB}$ for eight-hour workday and forty or forty two-hour workweek (Radić-Šestić and Žigić, 2006). According the international work organization about 120 million people have more or less hearing damage caused by the noice (MOR, 1993).

In the economy of the most prosperious countries, metal-working industry, especially the manufacturing industry takes the most significant places. The work conditions in this area, and especially the health protection problems which workers in this industry face have the crucial influence on the workers health state. Workers in the metal working industry are continually incured to the noises, where the intensity, usually, goes over the maximal level, which leads to hearing impairment.

Aim of the research: To establish the presence of the hearing impairment in metal-working industry (manufacturing area) under the work conditions effect, especially the noises and to compare the results with the hearing impairment registered in the general population. Also, the aim is to establish the presence of this profession among the people with hearing impairment and repercussion of this research on the professional orientation and training this population. Health protection in the metalworking industry conditions is also the aim of the research.

\section{The hypothesis:}

1. The working conditions provoke the frequency of the hearing damage appearance among the workers in the metal-working industry in the relation to the hearing impairment appearance in general population. The difference must be statistically significant.

2. The hearing impairment appearance among the workers in the metal-working industry is significantly connected with their years of work, i.e., hearing impairments are noticeable among the workers in the metal-working industry with the longer working years.

3. People with the hearing impairment are inadequately trained for the particular professions, especially the metal-working professions, because the metal-working industry conditions, additionally, complicate the hearing impairment consequences.

\section{METODS}

\section{Sampling}

The sample is made on a 1252 examinees, divided in the three sub samples. The first sub sample was made of 137 workers in the metal-working industry (manufacturing area). The second sub sample was made on a 1000 people of a general population, which is used as a sample for the establishing hearing impairment appearance at USA population and the third sub sample is made on a 106 adult people with hearing damage among the different professions. 
For the establishing hearing damage presence a through the influence of the working conditions in the metal-working industry and testing the hypothesis that the hearing impairment appearance among the workers in the metal-working industry is significantly connected with the years of their work, i.e., hearing impairments are noticeable among the workers in the metal-working industry with the longer working years. As the sub sample, the metal-working industry workers are observed. In order to test the hypothesis that working conditions, mostly, contribute to frequent hearing impairment appearance among the metal-working industry workers in relation to the hearing impairment appearance in general population and that the difference is statistically significant, the sub sample is compared to the sub sample consisted of people from general population.

In order to establish the presence of a metal profession among the people with the hearing impairment and to test the hypothesis that this kind of people are often trained inadequately, the sub sample consisted of a people with the hearing impairment is used.

\section{Measuring instrument}

Information about hearing impairment appearance among the workers in the metal-working industry are taken from the industrial medicine (pattern No.1-02-10), information about the qualified profession among the people with the hearing impairment are taken from the archive of canton communities of these people, while the information about the frequency of hearing impairment appearance in general population are taken from the Šarcer research (1966) (Radovančić, 1995).

\section{Methods of data processing}

Research data are processed by the parametric and nonparametric statistics. To look into global results, the descriptive analysis is used, the frequen- cies and percentages are counted and the graphic and tabular representation is made. To test the hypothesis that working conditions, mostly, contribute to frequent hearing impairment appearance among the workers in the metal-working industry, in relation to the hearing impairment appearance in global population and that the difference is statistically significant, the T-test is used.

And, to test the hypothesis that hearing damaged appearance among the workers in the metal-working industry is significantly linked to their years of work, i.e., hearing impairment is noticeable among the workers in the metal-working industry with longer period of work, the Pearson's coefficient of correlation is counted. The all data are processed in the statistical package SPSS 13.0 for Windows.

\section{RESULTS}

In the table 1 the analysis of frequency and percentages of the hearing impairment in relation to the life age among the general population and the workers in the metal-working industry is represented.

The evident differences are noticed from the results obtained from the two sub samples of examinees. Especially the enormous differences are noticed in the presence of hearing damage on a total amount of examinees in sub samples.

Among the general population, hearing damage appears in the $8.1 \%$, and among the workers in the metal-working industry in the $30.66 \%$ cases. Also there are enormous differences according to life age from 45 to 64 years old, where the hearing damage appears among the 37 workers between these years, from the 42 registered cases in the metal-working industry. 
Table 1. The analysis of frequencies and percentages of the hearing impairment presence in relation to the life age

\begin{tabular}{lcccc}
\hline & \multicolumn{2}{c}{ General population } & $\begin{array}{c}\text { Workers } \\
\text { working industry }\end{array}$ \\
\cline { 2 - 5 } Life age & \multicolumn{2}{c}{$\mathbf{N = 1 0 0 0}$} & \multicolumn{2}{c}{$\mathbf{N = 1 3 7}$} \\
\cline { 2 - 5 } & $\mathbf{f}$ & $\%$ & $\mathbf{f}$ & $\%$ \\
To 25 years & 7.6 & .76 & 2 & 5.41 \\
From 26 to 44 years & 22.2 & 2.22 & 3 & 8.11 \\
From 45 to 65 years & 51.2 & 5.12 & 37 & 2.01 \\
Total with the hearing impairment & $\mathbf{8 1}$ & $\mathbf{8 , 1}$ & $\mathbf{4 2}$ & $\mathbf{3 0 . 6 6}$ \\
\hline
\end{tabular}

Figure 1, clearly shows the results from the Table 1 , where the differences in the percentage presence of the hearing impairment among the two sub samples is clearly noticed.

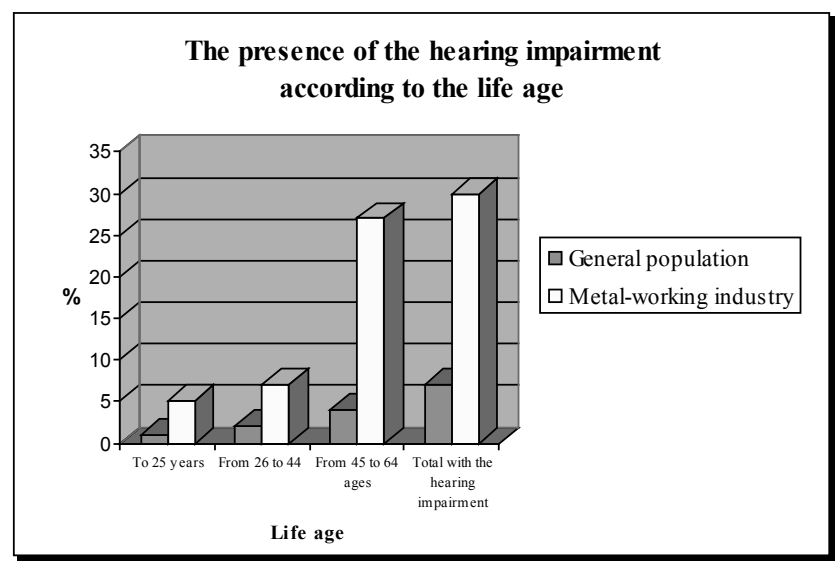

Figure 1. Percentage presence of the hearing impairment in relation to life age

In Table 2, the basic statistical parameters are represented: arithmetic mean, standard deviation, the lowest and the highest value of the hearing impairment presence of two sub samples examinees (general population and workers in the metalworking industry). The results showed noticeable differences in the above parameters, but to conclude the research it is necessary to test these parameters in order to confirm that the statistically significant differences between the two above sub samples of the examinees is about.
Table 2. The representation of the basic statistical parameters

\begin{tabular}{lcccc}
\hline \multicolumn{1}{c}{ Sub samples } & AM & SD & Min. & Max. \\
\hline General population & 27 & 22.19 & 7.2 & 51.2 \\
\hline Workers in the metal-workers industry & 14 & 19.92 & 2 & 37 \\
\hline
\end{tabular}

From the Table 3, it can be seen that testing the hypothesis about the differences between the arithmetic mean by the T-test between three different life ages, among the global population and among the workers in the metal-working industry, the gotten value $\mathrm{t}-3.27$, with the free level 2,and on the level of significance .05.

Table 3. Testing hypothesis over the difference between arithmetic means

\begin{tabular}{lccccc}
\hline \multicolumn{1}{c}{ Samples } & AM & SD & df & T-test & p \\
\cline { 1 - 3 } General population & 27 & 22,19 & & & \\
\cline { 1 - 3 } Workers in the metal-workers industry & 14 & 19,92 & 2 & 3.27 & .05 \\
\hline
\end{tabular}

In order to test the hypothesis that hearing damage appearance of the workers in the metal-working industry is significantly connected with the years of their work, the Pearson's coefficient of correlation is counted which is $r=.367$.

Looking into Table 4 and Figure 2, it can be noticed that metal professions are very presented among the people with the hearing damage, in the relation to the other types of professions. By questioning 106 people, 28 or $26.42 \%$ of them are of a metal profession.

Table 4. The presence of metal professions in the population of people with the hearing impairment

\begin{tabular}{lcc}
\hline \multicolumn{1}{c}{ Professions } & f & \% \\
\hline Metal professions & 28 & 26.42 \\
Textile professions & 24 & 22.64 \\
Leather professions & 9 & 8.49 \\
The rest 10 professions & 45 & 42.45 \\
\hline Total & $\mathbf{1 0 6}$ & $\mathbf{1 0 0}$ \\
\hline
\end{tabular}




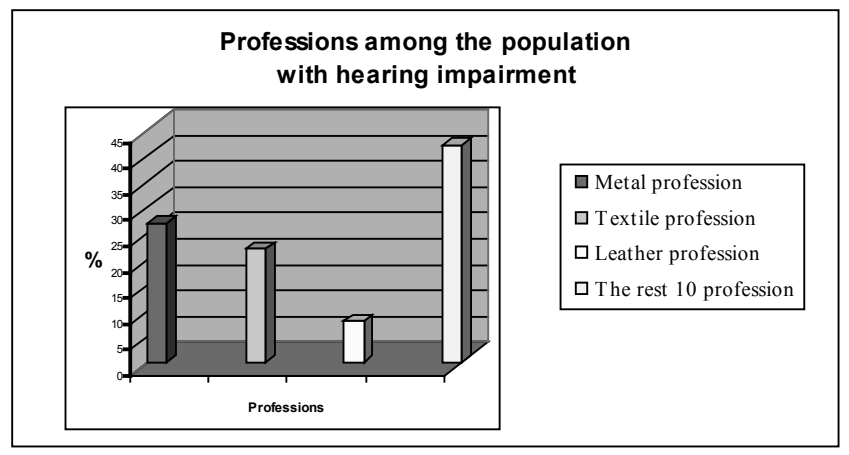

Figure 2. Metal professions among the population with the hearing impairment

\section{DISCUSSION}

Following the target of the research and establishing the hypothesis that working conditions, mostly, cause the hearing damage appearance among the workers in the metal-working industry, in relation to the same appearance in global population, and that the difference is statistically significant the comparative analysis of the frequency and percentage of the registered hearing impairment, is done in relation to life age, where the evident differences are noticed.

Testing the hypothesis by the T-test and getting the value $t=3.27$, with the free level 2 and the level of significance .05 , the statistically significant difference in the presence of hearing impairment among the two sub samples is established. On the basis of the all gotten results the hypothesis is confirmed. These results clearly point to the fact that is necessary to work more on the health protection of the workers in the metal-working industry. In the first place, the preventive measures of protection are needed. Based on the fact that work places in the manufacturing and textile industry, shipbuilding, work in the quarry, the forestry, work with the pneumatic and the electric hand-tools, work on the weaver's machines etc, are the places that bear a great factor of risk, the constant control of the hearing sense is needed (Kontošić, 2001).

Also, on the basis of the Pearson's coefficient of correlation and the gotten value $r=.367$, the mod- erate level of the connection between the hearing impairment and the working ages among the workers in the metal-working industry, is achieved.

According to the results, partially, it is possible to accept the fact that hearing damage appearance of the people in the metal-working industry is significantly connected to their working ages.

Otherwise, frequencies and percentages of the hearing damaged presence illustrate that presence of hearing damage is frequent among the people in the metal-working industry, of all life ages, in relation to the general population. Hence, the people of elder ages are put under this damage the most (ages between 45 and 65).

On the above given results about frequency of metal professions among the people with hearing damage and the achieved percentage which is $26.42 \%$, the hypothesis that people with the hearing impairment are often trained inadequately for these professions, is confirmed. These results are compatible with the results of the similar research made on the sub sample of 124 persons with hearing damage in Serbia, where the $35.55 \%$ of the people with the metal profession $30.67 \%$ of people with the textile profession and the rest belongs to the other professions, is registered (Ivanović, 1995). Also, the results about the frequency of hearing damage appearance in the metal working industry conditions, confirmed the second part of the hypothesis, i.e. working conditions are not suitable for their abilities and additionally complicate the hearing impairment consequences.

Former researches about the professional training of people with the hearing damage showed that over the 22 industry professionals the deaf people are mostly familiar with: metal-working, graphic, textile, book-binding, forestry, industry etc. ( Mašović, S. 1964. and Andrejević, 1992). According to this, as justification, a great search for these concerning are mentioned. For a particular period of time, it was thought that workers with the healthy sense of hearing should be replaced by 
those who have hearing impairment in the work places with a high level of noises, until the scientific researches showed that the damaged ear is more under the risk than the healthy one and that the working conditions in the noises could additionally complicate the state of a sense and lead to the bigger loss (Mašović, 1964).

In order to confirmed additionally, the necessity for the bigger scientific engagement in the realization of a professional orientation of the deaf people, the pilot researches are conducted in the particular factories of a chemical industry (cement factory, soda factory, coke processing)where the preliminary results showed that working conditions in these factories also cause the hearing damage.

According to the results, the number of people with the hearing damage is the smallest in a cement factory $(3 \%)$, and the highest number is in the coke factory (32\%), where the level of noises is also the highest. MOR asserts that diseases which follow the work include the diseases of a complex etiology, caused by numerous factors, and the working conditions are one of the possible cause of disease or they are the cause of the impairment caused by the unprofessional cause (Bogati-Šare).

\section{CONCLUSION}

Professional diseases are the significant measure for the evaluation of the risk in the work, because they can be a clear indicator of the working conditions harmful effect, and with the suitable correction, by the adequate work protection it is possible to reduce or to remove completely their appearance. Hence, it is necessary to reexamine former professional training of the deaf people, to approach to this problem with the serious and scientific manner, and to make working conditions more appropriate to workers and their health, in order to avoid serious consequences.

\section{REFERENCES}

Andrejević, D. (1992). Profesionalno osposobljavanje gluvih i nagluvih osoba. Srbija, Beograd: Zavod za udžbenike i nastavna sredstva.

Bogati-Šare, A. Procjena opasnosti oštećenja zdravlja u radnim uvjetima. Hrvatski zavod za medicinu rada.

International Labour Organization. (1998). Encyclopaedia of Occupational Health and Safety. 4. ed.

Ivanović, P. (1995). Šta gluhi kažu o svom: školovanju, profesionalnom osposobljavanju, zapošljavanju, radnom $i$ socijalnom statusu. Univerzitet u Beogradu. Defektološki fakultet. Beograd.

Kontošić, I. (2001). Opasnost se može čuti (Narodni zdravstveni list). Retrived April 16, 23, 2011, from www.zzjzpgz. hrnzl8sluh

Mašović, S. (1964). Profesionalno osposobljavanje gluhih. Beograd: Savezni odbor Saveza gluhih Jugoslavije.

MOR, 2003. Your health and safety at work. A collection of modules. Ergonomics Book.pp. 34-47.

Radić-Šestić M., Žigić, V. (2006). Uslovi rada i radne sredine. Beograd: Fakultet za specijalnu edukaciju i rehabilitaciju.

Radovančić, B. (1995). Osnove rehabilitacije slušanja $i$ govora. Zagreb: Fakultet za defektologiju Sveučilišta u Zagrebu. Savez organizacija osoba oštećena sluha Hrvatske. 